\title{
TAHAP BRAHMACARI ASRAMAPIJAKAN MENUJU TAHAP KEHIDUPANSEJAHTERA DAN BERKUALITAS
}

\author{
Oleh \\ Dra. Ni Wayan Sumertini., M.Ag. \\ Dosen pada Fakultas Brahma Widya IHDN Denpasar
}

\begin{abstract}
:
Hinduism recognizes the teachings of Catur Ashrama. Teachings of Catur Ashrama consists of Brahmacari, Grhasta, Wanaprastha, and Biksuka. Brahmacari is one of the most important things in the lives of children. At this level, man are at the learning stage. More and more age to learn. There is a science of art and technology that must be studied for the provision to the next stage of life. There is a religious ethic that must be occupied and lived as a life guide. There are many good things for formal, informal and non-formal education. The Brahmacari concept is a Hindu teaching in need in the Vedic scriptures that is very sublime for us to practice. The Brahmacari concept provides an explanation of the meaning of education for all of us who will impact on growth or bring benefits for ourselves, society and nation. Brahmacari is the only concept that is excellent and qualified.
\end{abstract}

Keywords: Brahmacari, Prosperous and Quality Life

\section{Pendahuluan}

Dalam agama Hindu diajarkan ajaran Asrama Dharma yaitu suatu tingkatan hidup yang harus dilalui oleh umat manusia, dari lahir hingga meningal dunia. Ada empat tingkatan atau tahapan yang harus dijalani manusia, yang disebut Catur Asrama. Catur berarti empat dan Asrama berarti tingkatan hidup menurut umur dengan hak dan kewajiban tertentu. Tahapan yang dimaksud ada 4 (empat) yaitu : 1) Brahmacari, merupakan metode belajar dan disiplin; 2) Grhasta adalah tahapan hidup manusia setelah menginjak dewasa memasuki tingkat dunia rumah tangga; 3) Wanaprasta adalah tahapan selanjutnya setelah Grhasta. secara harfiah wanaprasta berarti hidup di hutan, mulai meninggalkan ikatan keduniawian; 4) Sanyasin adalah tingkatan hidup yang melepaskan seluruh nafsu keduniawian (Nala dan Wiratmaja, 1995 :18-22).

Bramacari adalah tingkatan pertama dari CaturAsrama yang harus dilakukan oleh umat manusia dalam menjalani hidup di dunia ini. Pada tingkat ini, manusia berada pada tahapan belajar. Semakin bertambah umur semakin banyak yang harus dipelajari. Ada ilmu pengetahuan seni dan teknologi yang harus ditelaah untuk bekal dalam memesuki tahapan hidup selanjutnya. Ada etika agama yang harus ditekuni dan dihayati sebagai pedoman hidup. Ada banyak hal yang dipelajari baik melalui pendidikan formal, informal maupun nonformal. Belajar tidak selalu pada manusia, pada alam dan binatang pun manusia dapat belajar. Semua pengetahuan, keterampilan, kecakapan, kebiasaan, kegemaran dan sikap yang diperoleh semasa kehidupan Brahmacari merupakan potensi yang diperoleh akibat belajar dan sangat menentukan warna kehidupan selanjutnya. Belajar merupakan suatu aktivitas yang menghasilkan perubahan pada diri seseorang baik aktual maupun potensial. Perubahan ini merupakan kemampuan baru yang dapat dipergunakan sebagai bekal untuk hidup pada tingkat Grhasta, Wanaprasta dan Sanyasin.

Ilmu pengetahuan sangat penting dan utama, hal ini disebutkan dalam Bhagavadgita IV.36 yang menyatakan "Walaupun seandainya engkau paling bedosa diantara manusia yang memiliki dosa, dengan perahu ilmu pengetahuan ini, lautan dosa akan engkau seberangi" (Pudja, 
1999 :128).Hal yang sama juga diuraikan dalam ManawaDharmasastrai V.109 yang mengatakan "Tubuh dibersikan dengan air, pikiran disucikan dengan kebenaran, jiwa manusia dibersihkan dengan pelajaran suci dan tapabrata, kecerdasan dibersihkan dengan pengetahuan yang benar" (Pudja, 1996 :311).

Dengan kata lain Brahmacari Asrama merupakan tingkatan kehidupan yang sangat penting dalam kehidupan manusia karena pada masa ini kepribadian manusia itu dibentuk dan pada Brahmacari Asrama ini pula merupakan suatu pijakan menuju tahap kehidupan lebih lanjut yang sejahtera dan berkualitas.Kebijaksanaan pemerintah dalam bidang pendidikan adalah sebagai suatu usaha mengembangkan kepribadian utuh dan membangun sumber daya manusia berkualitas. Pelaksanaan Pendidikan berlangsung di sekolah maupun di luar sekolah dan berlangsung seumur hidup artinya individu belajar dan mengembangkan pengalaman tidak dibatasi oleh usia. Hal ini sesuai dengan UU RI No. 20 Tahun 2003 Bab III Pasal 4 Ayat (3) dan (6).

UU RI No. 20 Tahun 2003 Bab III Pasal 4 Ayat (3) menyatakan "Pendidikan diselenggarakan sebagai suatu proses pembudayaan dan pemberdayaan peserta didik yang berlangsung sepanjang hayat". UU RI No. 20 Tahun 2003 Bab III Pasal 4 Ayat (6) menyatakan bahwa "Pendidikan diselenggarakan dengan memberdayakan semua komponen masyarakat melalui peran serta dalam penyelenggaraan dan pengendalian mutu layanan pendidikan". Sedangkan pada UU RI No 20 Tahun 2003 Bab II Pasal 3 dikemukakan tentang fungsi dan tujuan pendidikan itu sendiri yaitu "Pendidikan nasional berfungsi mengembangkan kemampuan dan membentuk watak serta peradaban bangsa bermartabat dalam rangka mencerdaskan kehidupan bangsa, bertujuan untuk mengembangkan potensi peserta didik agar menjadi manusia beriman dan bertakwa kepada Tuhan Yang Maha Esa, berakhlak mulia, sehat, berilmu, cakap, kreatif, mandiri, dan menjadi warga negara demokratis serta bertanggung jawab" Untuk mencapai dasar dan tujuan pendidikan tersebut maka isi pendidikan mencakup : (1) Mempertinggi mental-moral-budi pekerti dan memperkuat keyakinan beragama, (2) Mempertinggi kecerdasan dan keterampilan, (3) Membina / mengembangkan fisik yang kuat dan sehat.(Tim Penyusun, 2003: 7-8).

\section{Pembahasan}

\subsection{Ajaran Brahmacari Dalam Pendidikan Ag- ama Hindu}

Asrama Dharma adalah suatu tngkatan hidup yang harus dilalui oleh umat manusia, dari lahir hingga meningal dunia. Ada empat tingkatan atau tahapan yang harus dijalani manusia, yang disebut Catur Asrama. Catur berarti empat dan Asrama berarti tingkatan hidup menurut umur dengan hak dan kewajiban tertentu. Semua manusia tanpa kecuali harus menjalani tingkat kehidupan ini. Sudah merupakan kodrat alam, manusia lahir sebagai bayi kemudian membesar sebagai orang dewasa, akhirnya menua dan mati. Siapapun tidak dapat mengelak dari kodrat alam ini. Manusia hanya mampu menunda kematian, tetapi tidak mampu menolak atau menghindarinya. Proses menua dapat diperlambat, tetapi untuk menghentikannya agar manusia tidak menjadi tua, seberapapun tinggi ilmu pengetahuan dan teknologi yang telah dikuasainya tidak akan berhasil. Proses ini akan berlangsung sepanjang jaman. Manusia tinggal mengikuti ajaran-Nya untuk menuju kesejahtraan dan kedamaian hidup sesuai dengan tingkat hidup yang dijalani (Nala dan Wiratmaja, 1995 :16).

Setiap manusia harus melewati Asrama yang berbeda secara teratur, tidak memasuki tahapan hidup sebelum waktunya. Manusia dapat memasuki tahapan berikutnya, bila tiaptiap tahapan sebelumnya telah di lalui. Di alam, evolusi berjalan secara bertahap dan tidak secara revolusioner. Tahapan yang dimaksud ada 4(empat) yaitu : 1) Brahmacari, merupakan metode belajar dan disiplin; 2) Grhasta adalah tahapan hidup manusia setelah menginjak dewasa memasuki tingkat dunia rumah tangga; 3) Wanaprasta adalah tahapan selanjutnya setelah Grhasta. Secara harfiah Wanaprasta berarti hidup di hutan, mulai 
meninggalkan ikatan keduniawian; 4) Sanyasin adalah tingkatan hidup yang melepaskan seluruh nafsu keduniawian (Nala dan Wiratmaja, 1995 :18-22).

Bramacari adalah tingkatan pertama dari CaturAsrama yang harus dilakukan oleh umat manusia dalam menjalani hidup di dunia ini. Pada tingkat ini, manusia berada pada tahapan belajar. Semakin bertambah umur semakin banyak yang harus dipelajari. Ada ilmu pengetahuan seni dan teknologi yang harus ditelaah untuk bekal dalam memesuki tahapan hidup selanjutnya. Ada etika agama yang harus ditekuni dan dihayati sebagai pedoman hidup. Ada banyak hal yang dipelajari baik melalui pendidikan formal, informal maupun nonformal. Belajar tidak selalu pada manusia, pada alam dan binatang pun manusia dapat belajar. Semua pengetahuan, keterampilan, kecakapan, kebiasaan, kegemaran dan sikap yang diperoleh semasa kehidupan Brahmacari merupakan potensi yang diperoleh akibat belajar dan sangat menentukan warna kehidupan selanjutnya. Belajar merupakan suatu aktivitas yang menghasilkan perubahan pada diri seseorang baik aktual maupun potensial. Perubahan ini merupakan kemampuan baru yang dapat dipergunakan sebagai bekal untuk hidup pada tingkat Grhasta, Wanaprasta dan Sanyasin.

Brahmacari terdiri dari dua kata yaitu Brahma yang berarti ilmu pengetahuan dan cari yang berarti tingkah laku dalam mecari dan menuntut ilmu pengetahuan. Brahmacari berarti tingkatan hidup bagi orang-orang yang sedang menuntut ilmu pengetahuan. Brahmacari dalam arti sempit adalah masa belajar secara formal misalnya belajar sejak TK sampai perguruan tinggi. Brahmacari dalam arti yang lebih luas, adalah upaya meningkatkan pengetahuan dengan berbagai cara (formal dan informal) yang berlangsung sepanjang masa kehidupan karena sebenarnya proses belajar-mengajar berlangsung tiada henti. Brahmacari dalam arti khusus ada dua yaitu:

1. Brahmacari dalam kaitan masa aguron-guron (belajar agama/ spiritual) seorang sisya (siswa) kepada Nabe (guruspiritual) di mana Nabe tidak hanya mengajar tetapi juga mendidik dan melatih, dan

2. Brahmacari dalam arti menjauhkan diri dari keinginan sex atau tidak kawin/ nikah selama hidup.

Kehidupan para pelajar di mulai dengan upacara Upanayana, sebagai hari kelahirannya yang kedua. Mereka harus dibuat tabah dan sederhana dalam kebiasaan-kebiasaan mereka harus bangun pagi-pagi, mandi melakukakan sandhya\&java gayatri serta mempelajari kitab-kitab suci. Menurut ajaran agama hindu, dalam BrahmacariAsrama, para siswa dilarang mengumbar hawa nafsu sex. Adapun hubungan antara perilaku seksual dan Brahmacari dapat di ketahui melalui istilah berikut :

\section{Sukla Brahmacari}

Orang yang tidak kawin semasa hidupnya, bukan karena tidak mampu, melainkan karena mereka sudah berkeinginan untuk nyukla Brahmacari sampai akhir hayatnya.

\section{SewalaBrahmacari}

Orang yang menikah sekali dalam masa hidupnya

\section{KresnaBrahmacari}

Pemberian ijin untuk menikah maksimal 4 kali karena suatu alasan yang tidak memungkinkan diberikan oleh sang istri, seperti isang istri tidak dapat menghasilkan keturunan, sang istri sakitsakitan, dan bila istri sebelumnya memberikan ijin.Brahmacari dalam arti khusus ada dua yaitu :1) Brahmacari dalam kaitan masa aguron-guron (belajar agama/spiritual) seorang sisya (siswa) kepada Nabe (guruspiritual) dimana Nabe tidak hanya mengajar tetapi juga mendidik dan melatih, dan 2) Brahmacari dalam arti menjauhkan diri dari keinginan sex atau tidak kawin/nikah selama hidup. Yang terakhir ini disebut sebagai sukhla Brahmacari. Pentingnya Brahmacari Ashrama, disebutkan dalam Atharvaveda sebagai berikut:

Brahmacaryena tapasa, raja rastram vi raksati, acaryo brahmacaryena, Brahmacarinam icchate (XI.5.17). Sa dadhara prthivim divam ca (XI.5.1). Tasmin devah sammanaso bha vanti (XI.5.1) 


\section{Artinya:}

Seorang pemimpin dengan mengutamakan Brahmacari dapat melindungi rakyatnya, dan seorang guru yang melaksanakan Brahmacari menjadikan siswanya orang yang sempurna; Seseorang yang melaksanka Brahmacari akan menjadi penopang kekuatan dunia; Tuhan (Hyang Widhi) bersemayam pada diri seorang Brahmacari.

Dari kutipan Veda itu jelaslah kiranya bahwa kewajiban manusia yang utama dan yang pertama dilakukan adalah menuntut ilmu atau belajar dan berpendidikan, karena dari pendidikan/ pengajaranlah pikiran dikembangkan untuk menuju kepada Catur PurushaArtaseperti yang telah dikemukakan dalam uraian tentang Catur Purusha Artaterdahulu. Pelajaran dan pendidikan juga akan membangun kemampuan berpikir untuk memilah antara dharma (perbuatan baik) dan adharma (perbuatan tidak baik) sehingga manusia dapat mencapai kesempurnaan hidup.Kitab Suci Sarasamusccaya 2 :

Manusah sarvabhutesu varttate vai subhasubhe, asubhesu samavistam subhesvevavakarayet.
Artinya :
Diantara semua mahluk hidup, hanya yang dilahirkan sebagai manusia sajalah yang dapat melaksanakan perbuatan baik atau- pun buruk, leburlah kedalam perbuatan baik segala yang buruk itu; demikianlah pahalanya menjadi manusia.

Dalam Upanisad disebutkan pula bahwa arti kataManusah adalah: Manu artinya kebijaksanaan, sah artinya mempunyai. Jadi manusia adalah mahluk yang mempunyai kebijaksanan. Kebijaksanaan diperoleh dari tiga kemampuan kodrati manusia yaitu Sabda (kemampuan berbicara), Bayu (kemampuan bergerak) dan Idep (kemampuan berpikir). "Idep" yang dituntun oleh ajaran agama dan ilmu pengetahuan akan menjadikan manusia itu lebih bijaksana sehingga disebut sebagai manusia yang sempurna. Mahluk lain seperti binatang hanya mempunyai dua kemampuan saja yaitu kemampuan bergerak (bayu) dan kemampuan bersuara (sabda). Binatang tidak mempunyai kemampuan berpikir (idep) oleh karena itu binatang beraktivitas berdasarkan naluri, tidak berdasarkan pikiran. Tumbuhtumbuhan hanya mempunyai kemampuan tumbuh (bayu) saja, tidak mempunyai sabda dan idep.Selanjutnya Sarasamusccaya menyatakan bahwa kita wajib bersyukur karena atman telah menjelma menjadi manusia, mahluk yang utama, karena itu gunakanlah kesempatan hidup yang sempit ini dengan sebaik-baiknya, kesempatan mana sungguh sangat sulit diperoleh; lakukanlah segala sesuatu yang baik (melalui Brahmacari) yang mencegah kejatuhan harkat kemanusiaan, gunakanlah kesempatan ini untuk mencapai moksa/sorga. "Paramarthanya, pengpengen ta pwa katemwaniking si dadi wwang, durlabha wi ya ta, saksat handaning mara ring swarga ika, sanimittaning tan tiba muwah ta pwa damelakena"

\subsection{Brahmacari Sebagai Konsep Belajar Seu- mur Hidup}

Menurut konsep Hindu, proses belajar itu sepanjang hidup. Dari masa Brahmacari, grhasta, vanaprastha sampai sanyasin Asrama.Menurut konsep kitab Agastia Parwa, dasar membangun pendidikan sepanjang masa ada dua yaitu menjadikan belajar sebagai tradisi atau kebiasaan hidup sehari-hari dan paham akan penggunaan aksara. Ilmu yang harus dicari itu adalah tentang dunia nyata atau sekala (Apara Vidya) dan ilmu tentang keberadaan dan kemahakuasaan Tuhan (Para Vidya). Mencari ilmu itu untuk bekal hidup agar bisa menata hidup sepanjang masa. Menimba ilmu bukan sekadar mengajarkan peserta didik mencari nafkah semata. Sebab, kebijakan struktural yang lebih menekankan pada pembangunan kesejahteraan material maka pendidikan pun ikut mengarah pada hal-hal lebih banyak pada yang materialistis.Hal ini seprti yang disebutkan dalam kutipan Agastia Parwa sebagai berikut :

Brahmacari ngarania sang mangabiasa Sang Hyang Sastra muang Sang Wruh ring kalingganing Sang Hyang Aksara. (Kutipan Agastia Parwa). 


\section{Terjemahannya :}

Brahmacari adalah mereka yang sedang mencari ilmu pengetahuan. Itu sebagai kebiasaan sehari-hari dan mereka yang paham akan hakikat penggunaan aksara.

Pembangunan yang mengarah pada ekonomi materialistis menyebabkan pendidikan mengalami krisis paradigma. Pendidikan sesungguhnya bukan sekadar investasi. Pendidikan "media beryadnya" untuk membangun generas penerus yang mampu mandiri. Kalau pendidikan dipandang sebagai investasi maka paradigmanya mengejar profit semata. Lulusannya pun akan cenderung berusaha mengembalikan investasi yang ditanam serta mendapatkan untung dengan segala cara.

Paradigma pendidikan yang lebih menekankan pada bisnis menyebabkan sekolah bagaikan "perusahaan pendidikan". Membangun kekuatan moral haruslah dengan paradigma pendidikan yang benar dan baik. Tidak hanya mencetak SDM yang haus rezeki, ingin serba cepat dan formalistis. Pendidikan harus diselenggarakan seimbang antara pendidikan formal, nonformal dan informal.Demikian juga dalam menjaga Bali hendaknya jangan dibiarkan lembaga-lembaga pendidikan menjadi "perusahaan pendidikan". Pendidikan hendaknya menjadi media beryadnya bagi pemerintah dan masyarakat mampu. Dengan proses pendidikan berdasarkan yadnya, diharapkan akan menghasilkan SDM yang siap beryadnya pada negara dan masyarakat. Bukan menghasilkan SDM yang siap mengorbankan uang negara dan uang masyarakat dengan segala cara.Kehidupan beragama Hindu di Bali hendaknya diarahkan untuk membangkitkan kesadaran pendidikan informal dan nonformal untuk mengimbangi pendidikan formal yang sudah mirip perusahaan. Tanpa membenahi paradigma pendidikan dalam membangun Bali maka Bali tidak akan ajeg.

\subsection{Pembangunan Pendidikan Dalam Menca- pai Kehidupan Yang Berkualitas.}

Berbicaratentang pendidikankita semuapasti sudah tahu bahwa betapa pentingnya hal tersebut. Pendidikan,kemampuan,pengetahuan merupakan salah satu modal yang kita miliki untuk hidup di zaman yang serba sulit ini.Mengapa dikatakan demikian?Kita tentu sudah bisa menjawabnya,apa hal pertama yang dilihat bila kita ingin mengajukan surat lamaran perkerjaan?Apa yang kita butuhkan ketika ingin memulai suatu bisnis atau usaha?Tentu saja pendidikan,kemampuan,wawasan dan pengetahuanlah yang kita butuhkan.Di dalam bangku pendidikan banyak sekali hal yang kita dapatkan.Tetapi entah mengapa banyak sekali warga di Indonesia ini yang tidak mengenyam bangku pendidikan sebagaimana mestinya,khususnya di daerah-daerah terpencil di sekitar wilayah Indonesia ini.Mungkin karena memang mereka mempunyai jalan pikiran yang sempit atau mungkin juga karena otak mereka tidak mampu untuk mengikuti pelajaran di bangku pendidikan tersebut.Jadi factor ekonomi bukan penyebab utamanya.

Sebagaimana yang diungkapkan Daoed Joesoef tentang pentingnya suatu pendidikan : "Pendidikan merupakan segala bidang penghidupan, dalam memilih dan membina hidup yang baik, yang sesuai dengan martabat manusia" Dan tentulah dari pernyataan tersebut kita bisa mengambil kesimpulan bahwa Pendidikan merupakan hal yang sangat penting dan tidak bisa lepas dari kehidupan, maka dari itu saya bisa membantah kata-kata "Pendidikan bukanlah segalanya" seperti apa yang Kepala Sekolah saya sendiri katakan.

Menjadi bangsa yang maju tentu merupakan cita-cita yang ingin dicapai oleh setiap negara di dunia. Sudah menjadi suatu rahasia umum bahwa maju atau tidaknya suatu negara di pengaruhi oleh faktor pendidikan. Begitu pentingnya pendidikan, sehingga suatu bangsa dapat diukur apakah bangsa itumajuataumundur, karna sepertiyangkita ketahui bahwa suatu Pendidikan tentunya akan mencetak Sumber Daya Manusia yang berkualitas baik dari segi spritual, intelegensi dan skill dan pendidikan merupakan proses mencetak generasi penerus bangsa. Apabila output dari proses pendidikan ini gagal maka sulit dibayangkan bagaimana dapat mencapai kemajuan. Bagi suatu bangsa yang ingin maju, pendidik harus dipandang sebagai sebuah kebutuhan sama halnya dengan kebutuhan- 
kebutuhan lainnya. Maka tentunya peningkatan mutu pendidikan juga berpengaruh terhadap perkembangan suatu bangsa. Kita ambil contoh Amerika, mereka takkan bisa jadi seperti sekarang ini apabila --maaf-- pendidikan mereka setarap dengan kita. Lalu bagaimana dengan Jepang? si ahli Teknologi itu? Jepang sangat menghargai Pendidikan, mereka rela mengeluarkan dana yang sangat besar hanya untuk pendidikan bukan untuk kampanye atau hal lain tentang kedudukan seperti yang--maaf-- Indonesia lakukan. Tak ubahnya negara lain, seperti Malaysia dan Singapura yang menjadi negara tetangga kita.

Dalam Pembukaan UUD 1945 dinyatakan bahwa salah satu tujuan negara adalah mencerdaskan kehidupan bangsa, dan oleh karena itu setiap warga negara Republik Indonesia berhak memperoleh pendidikan yang merata dan bermutu sesuai dengan minat dan bakat yang dimiliknya tanpa memandang status sosial, etnis dan gender sehingga sebagai anggota masyarakat akan memiliki afeksi, kecerdasan dan keterampilan yang akan berguna untuk mengenal dan mengatasi masalah dirinya dan lingkungannya, mendorong tegaknya masyarakat madani dan modern yang dijiwai nilai-nilai Pancasila. Untuk mencapai hat tersebut, Presiden mengeluarkan Peraturan Presiden Nomor 7 Tahun 2005 tentang Rencana Pembangunan Jangka Menengah Nasional (RPJMN) Tahun 2004-2009 yang mengamanatkan tiga misi pembangunan nasional, yaitu: 1) Mewujudkan negara Indonesia yang aman dan damai, 2) Mewujudkan bangsa Indonesia yang adil dan demokratis, dan 3) Mewujudkan bangsa Indonesia yang sejahtera.

Untuk mewujudkan masyarakat yang aman, adil, dan sejahtera, bangsa Indonesia harus memiliki sumber daya manusia (SDM) yang berkualitas. Oleh karena itu, kebijakan pendidikan nasional harus mampu mewujudkan pemerataan pendidikan yang bermutu sebagaimana amanat penting yang harus diemban oleh pemerintah dalam mencerdaskan kehidupan bangsa. Hat itu merupakan prasyarat untuk meningkatkan kualitas hidup dan produktivitas bangsa Indonesia yang sejajar dengan bangsa lain di era global, yang ditandai oteh persaingan internasional yang makin ketat. Dengan demikian, perspektif pembangunan pendidikan masa yang akan datang tidak hanya ditujukan untuk mengembangkan aspek intelektual saja melainkan juga watak, moral, sosial dan fisik perserta didik, atau dengan kata lain menciptakan manusia Indonesia seutuhnya.

Upaya untuk membangun manusia seutuhnya sudah menjadi tekad pemerintah sejak Rencana Pembangunan Lima Tahun (REPELITA) I Tahun 1969-1974. Namun pembangunan pendidikan nasional selama ini belum mencapai hasit sesuai yang diharapkan. Departemen Pendidikan Nasional (Depdiknas) perlu memiliki strategi dan program untuk mewujudkan cita-cita yang luhur itu. Sebagai acuannya, Depdiknas menyusun Rencana Strategis.

Pembangunan Pendidikan Nasional (Renstra Depdiknas) Tahun 2005-2009 yang merupakan penjabaran dari Rencana Pembangunan Jangka Menengah Nasional. Renstra ini menjadi pedoman bagi semua tingkatan pengelola pendidikan, mulai dari pemerintah pusat, daerah, masyarakat dan satuan pendidikan, untuk merencanakan dan melaksanakan program pembangunan pendidikan nasional serta mengevaluasi hasilnya.

Pembangunan pendidikan nasional tidak dapat lepas dari perkembangan lingkungan strategic, baik nasional maupun global. Pendidikan harus dibangun dalam keterkaitannya secara fungsional dengan berbagai bidang kehidupan, yang masing-masing memiliki persoalan dan tantangan yang semakin kompleks. Dalam dimensi sektoral tersebut, pembangunan pendidikan tidak cukup hanya berorientasi pada pembangunan sumber daya manusia (SDM) dalam rangka menyiapkan tenaga kerja. Dalam lima tahun ke depan, pembangunan pendidikan nasional harus dilihat dalam perspektif pembangunan manusia Indonesia seutuhnya. Dalam perspektif demikian, pendidikan harus lebih berperan dalam membangun seluruh potensi manusia agar menjadi subyek yang berkembang secara optimal dan bermanfaat bagi masyarakat dan pembangunan nasional. Potensi manusia Indonesia yang dikembangkan mencakup olah hati yang berkualitas dengan keimanan, 
ketakwaan dengan akhlak mulia, olah rasa yang berkualitas dengan seni atau estetika, olah pikir yang berkualitas dengan ilmu pengetahuan dan teknologi, serta potensi fisik yang berkualitas dengan olah raga.

Pembangunan pendidikan nasional adalah suatu usaha yang bertujuan untuk mewujudkan masyarakat Indonesia yang berkualitas, maju, mandiri, dan modern. Pembangunan pendidikan merupakan bagian penting dari upaya menyeturuh dan sungguh-sungguh untuk meningkatkan harkat dan martabat bangsa. Keberhasilan dalam membangun pendidikan akan memberikan kontribusi besar pada pencapaian tujuan pembangunan nasional secara keseluruhan. Dalam konteks demikian, pembangunan pendidikan itu mencakup berbagai dimensi yang sangat luas: sosial, budaya, ekonomi, dan politik.

Dalam perspektif sosial, pendidikan akan melahirkan insan-insan terpelajar yang mempunyai peranan penting dalam proses perubahan sosial di dalam masyarakat. Pendidikan menjadi faktor determinan dalam mendorong percepatan mobilitas masyarakat, yang mengarah pada pembentukan formasi sosial baru. Formasi sosial baru ini terdiri atas lapisan masyarakat kelas menengah terdidik, yang menjadi elemen penting dalam memperkuat daya rekat sosial (social cohesion). Pendidikan yang melahirkan tapisan masyarakat terdidik itu menjadi kekuatan perekat yang menautkan unit-unit sosial di dalam masyarakat: ketuarga, komunitas, perkumpulan masyarakat, dan organisasi sosial yang kemudian menjelma dalam bentuk organisasi besar berupa tembaga negara. Dengan demikian, pendidikan dapat memberikan sumbangan penting pada upaya memantapkan integrasi sosial.

Dalam perspektif budaya, pendidikan juga merupakan wahana penting dan medium yang efektif untuk mengajarkan norma, mensosialisasi nilai, dan menanamkan etos di kalangan warga masyarakat. Pendidikan juga dapat menjadi instrumen untuk memupuk kepribadian bangsa, memperkuat identitas nasional, dan memantapkan jati diri bangsa. Bahkan peran pendidikan menjadi lebih penting lagi ketika arus globalisasi demikian kuat, yang membawa pengaruh nitai-nitai dan budaya yang acapkali bertentangan dengan nitainitai dan kepribadian bangsa Indonesia. Dalam konteks ini, pendidikan dapat menjadi wahana strategis untuk membangun kesadaran kotektif (collective conscience) sebagai warga bangsa dan mengukuhkan ikatan-ikatan sosial, dengan tetap menghargai keragaman budaya, ras, sukubangsa, dan agama, sehingga dapat memantapkan keutuhan nasional.

Dalam perspektif ekonomi, pendidikan akan menghasilkan manusiamanusia yang andal untuk menjadi subyek penggerak pembangunan ekonomi nasional. Oleh karena itu, pendidikan harus mampu melahirkan lulusan-lulusan bermutu yang memiliki pengetahuan, menguasai teknologi, dan mempunyai keterampilan teknis yang memadai. Pendidikan juga harus dapat menghasilkan tenaga-tenaga profesional yang memiliki kemampuan kewirausahaan, yang menjadi salah satu pilar utama aktivitas perekonomian nasional. Bahkan peran pendidikan menjadi sangat penting dan strategic untuk meningkatkan daya saing nasional dan membangun kemandirian bangsa, yang menjadi prasyarat mutlak dalam memasuki persaingan antarbangsa di era global. Di era global sekarang ini, berbagai bangsa di dunia telah mengembangkan knowledge-based economy (KBE), yang mensyaratkan dukungan sumber daya manusia (SDM) berkualitas. Karena itu, pendidikan mutlak diperlukan guna menopang pengembangan ekonomi berbasis pengetahuan education for the knowledge economy (EKE). Dalam konteks ini, lembaga pendidikan harus pula berfungsi sebagai pusat penelitian dan pengembangan (research and development), yang menghasilkan produk-produk riset unggulan yang mendukung KBE. Ketersediaan SDM bermutu yang menguasai iptek sangat menentukan kemampuan bangsa dalam memasuki kompetensi global dan ekonomi pasar bebas, yang menuntut daya saing tinggi. Dengan demikian, pendidikan diharapkan dapat mengantarkan bangsa Indonesia meraih keunggulan dalam persaingan global.

Dalam perspektif politik, pendidikan harus mampu mengembangkan kapasitas individu 
untuk menjadi warga negara yang baik (good citizens), yang memiliki kesadaran akan hak dan tanggung jawab dalam kehidupan bermasyarakat, berbangsa, dan bernegara. Karena itu, pendidikan harus dapat melahirkan individu yang memiliki visi dan idealisme untuk membangun kekuatan bersama sebagai bangsa. Visi dan idealisme itu haruslah merujuk dan bersumber pada paham ideologi nasional, yang dianut oleh seluruh komponen bangsa. Dalam jangka panjang, pendidikan niscaya akan melahirkan lapisan masyarakat terpelajar yang kemudian membentuk critical mass, yang menjadi elemen pokok dalam upaya membangun masyarakat madani. Dengan demikian, pendidikan merupakan usaha besar untuk meletakkan landasan sosial yang kokoh bagi terciptanya masyarakat demokratis, yang bertumpu pada golongan masyarakat Was menengah terdidik yang menjadi pilar utama civil society, yang menjadi salah satu tiang penyangga bagi upaya perwujudan pembangunan masyarakat demokratis.

Dalam lima tahun mendatang, pembangunan pendidikan nasional dihadapkan pada berbagai tantangan serius, terutama dalam upaya meningkatkan kinerja yang mencakup: (i) pemerataan dan perluasan akses, (ii) peningkatan mutu, relevansi, dan daya saing (iii) penataan governance, akuntabilitas, dan pencitraan diri, dan (iv) peningkatan pembiayaan. Dalam upaya meningkatkan kinerja pendidikan nasional, diperlukan suatu reformasi menyeluruh yang telah dimulai dengan kebijakan desentralisasi dan otonomi pendidikan sebagai bagian dari reformasi politik pemerintahan. Reformasi politik pemerintahan ini tertuang di dalam UU No. 22/1999, yang kemudian disempurnakan menjadi UU No. 32/2004 tentang Pemerintahan Daerah. UU tersebut menandai perubahan radikal tata kepemerintahan dari sistem sentralistik ke sistem desentralistik, dengan memberikan otonomi yang luas kepada daerah. Pendidikan yang semula menjadi kewenangan pemerintah pusat kemudian dialihkan menjadi kewenangan pemerintah daerah. Pengelolaan pendidikan yang menjadi wewenang pemerintah daerah ini dimaksudkan untuk meningkatkan efisiensi dan efektivitas manajemen pendidikan, sehingga diharapkan dapat memperbaiki kinerja pendidikan nasional.

Dalam era otonomi dan desentralisasi, sistem pendidikan nasional dituntut untuk melakukan berbagai perubahan, penyesuaian, dan pembaharuan dalam rangka mewujudkan pendidikan yang otonom dan demokratis, yang memberi perhatian pada keberagaman dan mendorong partisipasi masyarakat, tanpa kehilangan wawasan nasional. Dalam konteks ini, pemerintah bersama dengan DPR-RI telah menyusun UU No. 20/2003 tentang Sistem Pendidikan Nasional sebagai perwujudan tekad dalam melakukan reformasi pendidikan untuk menjawab berbagai tantangan dalam kehidupan bermasyarakat, berbangsa, dan bernegara di era persaingan global.

\subsection{Konsep Brahmacari dalam Mewujudkan Kehidupan yang Berkualitas}

Brahmacari sebagai ajaran Hindu yang terdapat dalam kitab suci Agama Hindu merupakan suatu konsep ajaran yang sangat mulia dan sangat penting untuk dapat kita amalkan dalam kehidupan ini. BrahmacariAsrama merupakan masa-masa yang paling tepat untuk kita dalam menuntut ilmu yang sedalam-dalamnya guna mempersiapkan masa depan yang sukses dan membentuk kehidupan yang berkualitas. Pada tingkatan Brahmacari Asrama diharapkan kita mampu mendapatkan pendidikan yang optimal karena pendidikan merupakan segala bidang penghidupan, dalam memilih dan membina hidup yang baik, yang sesuai dengan martabat manusia.

Pendidikan adalah usaha sadar dan terencana untuk mewujudkan suasana belajar dan proses pembelajaran agar peserta didik secara aktif mengembangkan potensi dirinya sehingga memiliki kekuatan spiritual keagamaan, pengendalian diri, kepribadian, kecerdasan, akhlak mulia, serta keterampilan yang diperlukan oleh dirinya, masyarakat, banga dan Negara. Jadi pembangunan pembangunan pendidikan 
yang dalam ajaran Hindu dikenal dengan konsep Brahmacari Asrama merupakan suatu ajaran yang luhur dalam mewujudkan suksesnya pendidikan nasional yang nantinya sangat berpengaruh pada majunya atau peradaban suatu bangsa.

Menjadi bangsa yang maju tentu merupakan cita-cita yang ingin dicapai oleh setiap negara di dunia. Sudah menjadi suatu rahasia umum bahwa maju atau tidaknya suatu negara di pengaruhi oleh faktor pendidikan. Begitu pentingnya pendidikan, sehingga suatu bangsa dapat diukur apakah bangsa itu maju atau mundur, karna seperti yang kita ketahui bahwa suatu Pendidikan tentunya akan mencetak Sumber Daya Manusia yang berkualitas baik dari segi spritual, intelegensi dan skill dan pendidikan merupakan proses mencetak generasi penerus bangsa. Apabila output dari proses pendidikan ini gagal maka sulit dibayangkan bagaimana dapat mencapai kemajuan. Bagi suatu bangsa yang ingin maju, pendidik harus dipandang sebagai sebuah kebutuhan sama halnya dengan kebutuhan-kebutuhan lainnya. Maka tentunya peningkatan mutu pendidikan juga berpengaruh terhadap perkembangan suatu bangsa.

Kita sebagai umat yang beragama Hindu hendaknya senantiasa dapat mengamalkan ajaran Brahmacari ini dengan sebaik-baiknya karena selain berguna untuk kita sendiri juga dapat bermanfaat bagi kemajuan bangsa kita sendiri. Generasi muda Hindu penerus bangsa diharapkan memperoleh pendidikan yang layak sebagai bekal bagi masa depan mereka nanti. Dan hendaknya bagi generasi muda sekarang jangan sekali-kali melakukan tindakan-tindakan yang tidak bermanfaat atau yang lebih cenderung merugikan diri mereka sendiri. Gunakanlah waktu kita ini untuk menuntut ilmu sebanyakbanyaknya karena akan sangat berguna bagi masa depan kita dan bangsa ini.

\section{Penutup}

Brahmacari Asrama merupakan tingkatan kehidupan yang sangat penting dalam kehidupan manusia karena pada masa ini kepribadian manusia itu dibentuk dan pada Brahmacari Asrama ini pula merupakan suatu pijakan menuju tahap kehidupan lebih lanjut yang sejahtera dan berkualitas. Pada tingkat ini, manusia berada pada tahapan belajar. Semakin bertambah umur semakin banyak yang harus dipelajari. Ada ilmu pengetahuan seni dan teknologi yang harus ditelaah untuk bekal dalam memesuki tahapan hidup selanjutnya. Ada etika agama yang harus ditekuni dan dihayati sebagai pedoman hidup. Ada banyak hal yang dipelajari baik melalui pendidikan formal, informal maupun nonformal.

Konsep Brahmacari merupakan ajaran Hindu yang terdapat dalam kitab suci Weda yang sangat luhur untuk kita amalkan. Konsep Brahmacari memberikan penjelasan bagaimana pentingnya pendidikan bagi kita semua yang secara umum akan berimbas pada kemajuan atau membawa dampak positif bagi kita sendiri, masyarakat dan bangsa ini. Brahmacari merupakan suatu konsep yang sangat baik dalam upaya manusia memperoleh kehidupan yang baik dan berkualitas.

\section{DAFTAR PUSTAKA}

Ekosusilo, Madya dan Kusihadi,tt. Dasar- Dasar Pendidikan. Semarang: Effar Publishing.

Djamarah, Saiful Bahri. 2002. Psikologi Belajar. Jakarta: PT. Rineka Cipta.

Nala, I Gusti Ngurah dan Wiratmaja, I. G. K. Adiya. 1995. Murddha Agama Hindu. Denpasar: Upaya Sastra.

Nasution. 1983. Sejarah Pendidikan Indonesia. Bandung: Jemmars.

Pudja, G. 1999. Bhagawad Gita. Surabaya: Paramitha.

Siwananda, Sri Swami. 1963. intisari Ajaran Hindu. Surabaya: Paramitha.

Soecipto, w. 1979. Pengantar Ilmu Pendidikan. Tp.

Suwarno. 1992. Pengantar Umum Pendidikan. Jakarta: Rineka cipta.

Tim. 2003. Undang- Undang Sistem Pendidikan Nasional. Jakarta: Sinar Grafika. 
Sumber Internet :

www.hindubatam.com/catur-asrama.html

www.babadbali.com/canangsari/pa-caturasrama.htm

www.scribd.com/doc/10857091/pembangunanpendidikan 